Meta

Journal des traducteurs

Translators' Journal

\title{
Textual and Visual Aids for E-learning Translation Courses
}

\section{María Isabel Tercedor-Sánchez, Clara Inés López-Rodríguez et Bryan Robinson}

Volume 50, numéro 4, décembre 2005

Pour une traductologie proactive - Actes

For a Proactive Translatology - Proceedings

Por una traductología proactiva - Actas

URI : https://id.erudit.org/iderudit/019904ar

DOI : https://doi.org/10.7202/019904ar

Aller au sommaire du numéro

Éditeur(s)

Les Presses de l'Université de Montréal

ISSN

0026-0452 (imprimé)

1492-1421 (numérique)

Découvrir la revue

Citer cet article

Tercedor-Sánchez, M. I., López-Rodríguez, C. I. \& Robinson, B. (2005). Textual and Visual Aids for E-learning Translation Courses. Meta, 50(4).

https://doi.org/10.7202/019904ar

\section{Résumé de l'article}

La méthodologie d'un cours en ligne est basé sur une stratégie d'apprentissage autonome, dont l'étudiant est l'élément clé. Sous cette perspective éducative, le professeur devient l'élément qui facilite le processus d'apprentissage. Dans le contexte de la conception de cours de traduction destinés à l'enseignement en ligne, le professeur doit considérer que l'étudiant affronte des tâches qui requièrent la conception préalable d'activités facilitant aussi bien le processus de traduction proprement dit que l'acquisition de connaissances expertes pour mener à bien ces tâches. En outre, cette conception devrait être le reflet de nouvelles structures multimédias présentes au sein de la société de l'information.

Cette étude présente une série d’activités types créées grâce à un matériel aussi bien visuel que textuel et mises en oeuvre pour les matières de traduction scientifique, technique et audiovisuelle. Ces matières sont disponibles sur la plateforme de téléenseignement WebCT. Lesdites activités prétendent être utiles pour d'autres matières puisqu'elles facilitent la communication entre étudiants, tout en développant un cadre méthodologique qui permet d'acquérir des compétences lexicales, phraséologiques, culturelles et textuelles. Dans la conception des activités, l'accent a été mis sur l'autoévaluation de la part des étudiants.
Ce document est protégé par la loi sur le droit d'auteur. L'utilisation des services d’Érudit (y compris la reproduction) est assujettie à sa politique d'utilisation que vous pouvez consulter en ligne.

https://apropos.erudit.org/fr/usagers/politique-dutilisation/ 


\title{
Textual and Visual Aids for E-learning Translation Courses $^{*}$
}

\author{
MARÍA ISABEL TERCEDOR-SÁNCHEZ \\ CLARA INÉS LÓPEZ-RODRÍGUEZ \\ BRYAN ROBINSON \\ University of Granada, Granada, Spain \\ itercedo@ugr.es, clarailr@ugr.es, robinson@ugr.es
}

\begin{abstract}
RÉSUMÉ
La méthodologie d'un cours en ligne est basé sur une stratégie d'apprentissage autonome, dont l'étudiant est l'élément clé. Sous cette perspective éducative, le professeur devient l'élément qui facilite le processus d'apprentissage. Dans le contexte de la conception de cours de traduction destinés à l'enseignement en ligne, le professeur doit considérer que l'étudiant affronte des tâches qui requièrent la conception préalable d'activités facilitant aussi bien le processus de traduction proprement dit que l'acquisition de connaissances expertes pour mener à bien ces tâches. En outre, cette conception devrait être le reflet de nouvelles structures multimédias présentes au sein de la société de l'information.

Cette étude présente une série d'activités types créées grâce à un matériel aussi bien visuel que textuel et mises en œuvre pour les matières de traduction scientifique, technique et audiovisuelle. Ces matières sont disponibles sur la plateforme de téléenseignement WebCT. Lesdites activités prétendent être utiles pour d'autres matières puisqu'elles facilitent la communication entre étudiants, tout en développant un cadre méthodologique qui permet d'acquérir des compétences lexicales, phraséologiques, culturelles et textuelles. Dans la conception des activités, l'accent a été mis sur l'autoévaluation de la part des étudiants.
\end{abstract}

\begin{abstract}
The methodology of an e-learning course is based on the strategies of proactive learning, focused on the student as the key element of an approach to training in which the teacher acts as a facilitator of the learning process. Within the context of the design of a translation course in an e-learning context, the teacher must bear in mind that the student is faced with tasks that require the previous design of aids that help both in the translation process and in the acquisition of field knowledge to carry them out. Furthermore, the design should reflect the new multimedia structures that the information society has brought about.

We present a series of activities generated with both visual and textual material implemented in the design of e-learning courses in audiovisual translation (subtitling and multimedia), technical and scientific translation. One of the courses is accessible through the WebCT e-learning platform, another uses the $\mathrm{BSCW}^{\mathrm{TM}}$ collaborative learning platform and the virtual classroom www.aulaint.ugr.es. The activities are intended to be of use for other subjects too, since they facilitate communication between students and act at the levels of lexical, phraseological, textual and cultural competence. Emphasis is put on the students' self-assessment of their progress.
\end{abstract}

\section{MOTS-CLÉS/KEYWORDS}

e-learning course, visual, text, proactive learning, translation training

\section{Introduction}

Since the publication of the Bologna Declaration in 1999, in the European Union much attention has been paid to one of its key points: the challenge of a European Space for Higher Education.

Within such a space, The E-learning initiative was launched by the European Commission in 2000 to pursue both an improvement in quality standards and a response to the challenges of the so called Information Society (Castells 1996) at different levels. One of the main goals of such project 
is the development of pedagogical tools to enhance alternative approaches to classroom teaching of university classes. At a local level, the last stage of the eEspaña program calls for the incorporation of online resources for teaching as a support for contact classes: "incorporación de recursos online para fines docentes que sirvan de apoyo a la formación presencial -aulas y campus virtuales-" (Fundación Auna 2004).

In this paper, we describe a series of activities for the implementation of e-learning courses in the context of audiovisual, scientific and technical translation at university level.

\title{
2. Translation and e-learning today: methodological and teaching principles
}

\author{
The innovator, however, must in the first place be discontented, he must doubt the value of what he is \\ doing or question the accepted ways of doing it. And secondly, he must be prepared to take fresh paths, to \\ venture into fields where he is by no means expert. (Passmore 1970: 282)
}

In order to contribute with any useful material to a particular community, every teaching and research endeavour must be based on solid methodological premises. When developing an elearning initiative, as a starting point, one must reconsider the IRS "teacher Initiates, student Responds, teacher evaluates" sequence in such a fashion that an exchange of roles takes place in a classroom - physical or virtual- in which teachers act as facilitators in the learning process. In this context, it is necessary to emphasize the proactive component of the learning process. Social constructivism has proved efficient in achieving this aim in translation studies (Kiraly 2000; González Davies 2004). The authors of the present paper explored different paths to acknowledge the challenge of syllabus design in scientific, technical and audiovisual translation for e-learning at university level. One of the key elements is the preparation of frame activities which serve the function of "scaffolding" (Kiraly 2000: 45) aimed at creating more learner autonomy and thus making the learning and assessment processes more professional. The main objective was searching for the learners' autonomous work and progress via the use of e-learning platforms. In our approach to translation teaching, e-learning is considered to be simply an instrument to offer learners a close-up of real-world conditions, not as a panacea.

Following is a description of the frame activities we have designed and the particular translation strategies and competences they develop.

\section{Acquiring decoding strategies through basic corpus analysis}

The use of corpora has been explored by a number of authors in the context of teaching scientific and technical translation (e.g. Bowker 1998; Faber et al. 2001; Halverson 1998; Kenny 2001). What follows is a description of the activities performed by our students with the use of learner corpora made up of comparable and parallel corpora in scientific and technical translation. We define parallel text corpora as "sets of translation equivalent texts, in which generally one text is the source text and the other(s) are translations" (Peters et al. 1996; 1997: 254). Therefore, a type of parallel corpus would be a learner corpus made up of original texts and student translations. Comparable corpora, on the other hand, have been defined as collections of "texts which, though composed independently in the respective language communities, have the same communicative function" (Laffling 1992). Thus, they are not translation equivalents but are texts selected on the basis of shared essential features such as date of publication, discourse community, topic, function, style, genre, register, sublanguage or domain. Within our courses, we have been using comparable English and Spanish corpora compiled for a R\&D project aimed at building a knowledge base on Coastal Engineering.

Corpus analysis of original texts (comparable corpora) can be used to develop textual aids that enable users to:

a) acquire field knowledge and relevant recurrent cognitive structures

b) assess different intercultural and interlinguistic conceptual frames 
Terminological data banks and expert systems have been extensively recognized as a key element in accessing specialized knowledge. However, these generally work at an abstract level and require a previous basic understanding of the domain under study. Corpus analysis can be a powerful tool in teaching translation since learners can access the lexical item and learn its relevant contextual and cotextual information and know to analyze the interrelations between these.

Following are two examples of activity-types to illustrate the above premises. When faced with the translation of a text such as the one below (Fig.1) describing a basic event, in our case the definition of "wave" and its elements, the translation students need a clear idea of the basic concepts that shape the domain. Students can gain an understanding of these concepts in a corpus based manner if we provide the student with the relevant corpus concordance analysis to do so.

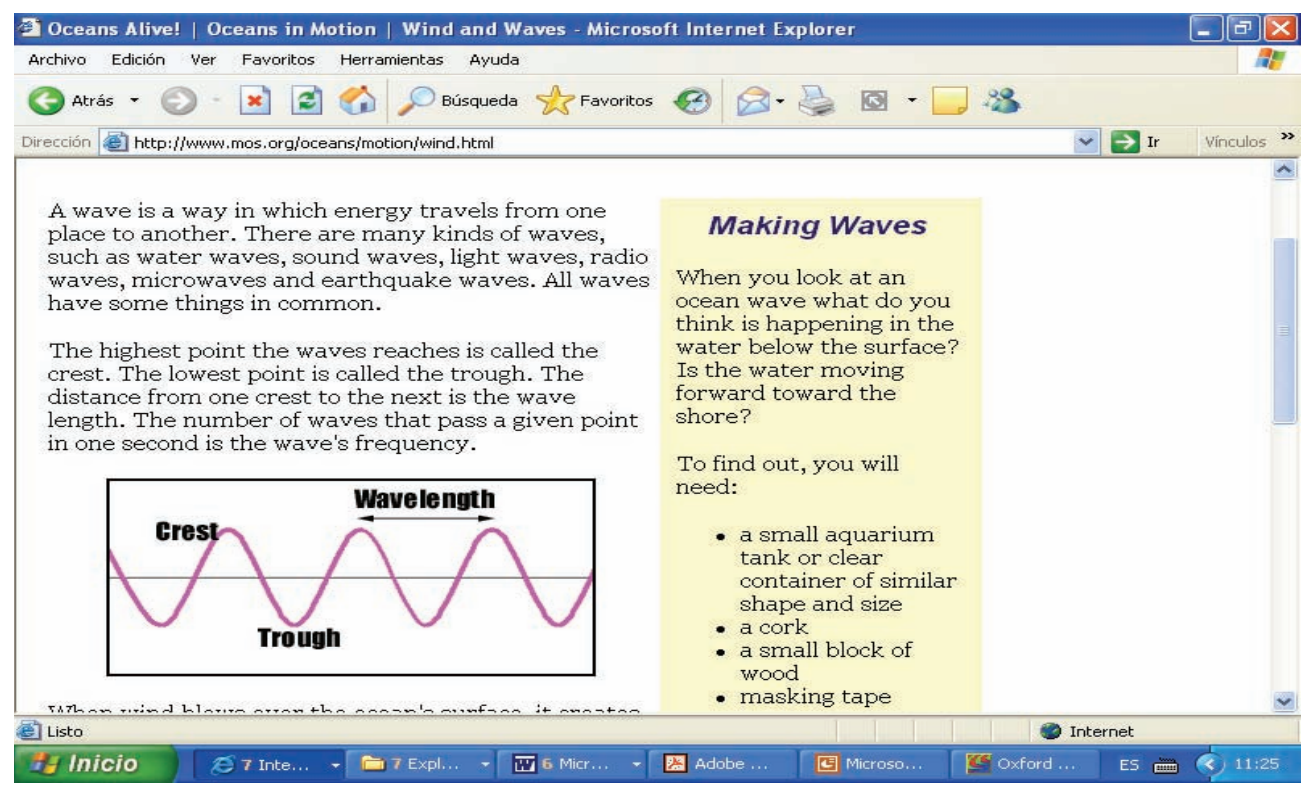

Figure 1. Basic text on "waves" aimed at secondary school students.

Here (fig.2) is a concordance of the equivalent of the lexical item in Spanish. Sorting the concordance to the left of the lexical item ("ola") under study, prompts us to see the basic concepts that shape the domain in question.

Through examples of concordance such as these, which we term "conceptual concordance", the student can learn all the basic concepts related to wave at a glance.

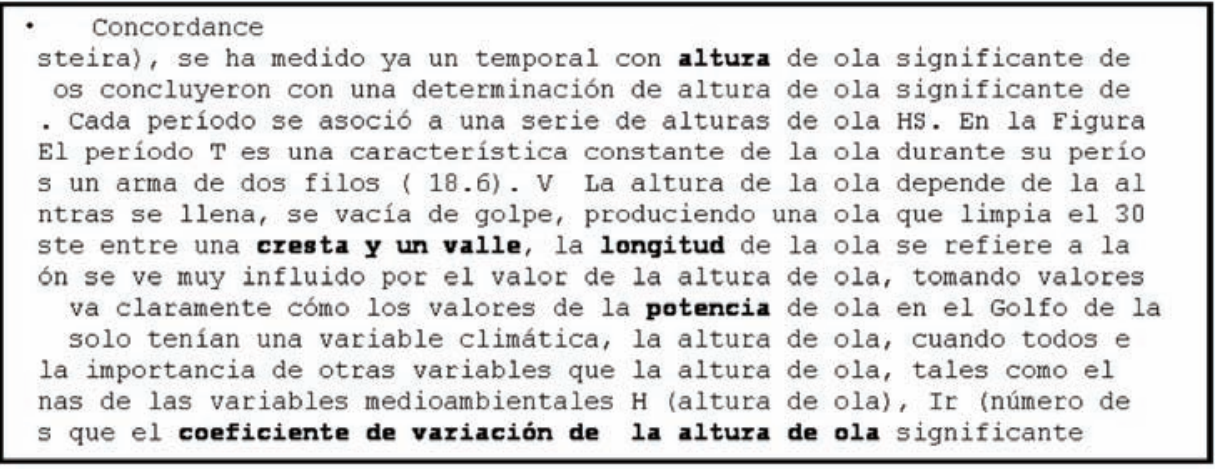

Figure 2. Left context Spanish "conceptual concordance" of the word "ola". 
In bold are the basic concepts that shape the conceptual domain surrounding "wave".

The example below (Fig. 3) demonstrates the main application of using a corpus in a translation class: learning the context and cotext of a particular item and inferring the relevant collocational data: e.g. "playa fluvial artificial", "playa fluvial natural". However, a closer look at the phraseology of the concordance can tell us about conceptual relations in the domain: antonymous relations such as "playa abierta" vs. "playa abrigada", "playa emergida" vs. "playa sumergida" or "playa arenosa" vs. "playa rocosa".

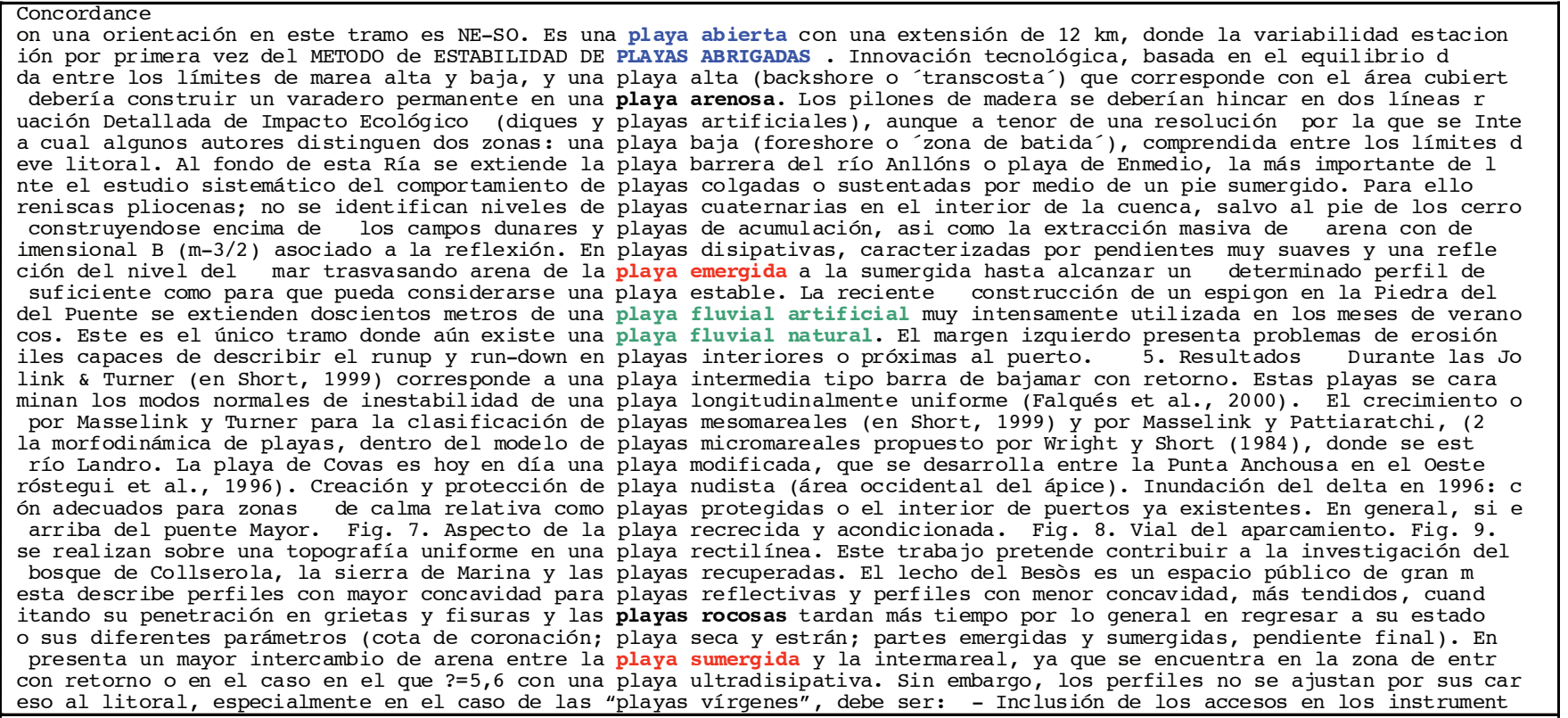

Figure 3. Spanish centered concordance of the search item "playa*".

\section{Threefold approach to self assessment}

One of the main challenges for a web-based translation course is generating well-designed self assessment tools. The following considerations have proved useful in our research.

\subsection{Self assessment through the use of learners' corpora}

Parallel corpora made from original texts and student translations of those texts can be a powerful tool to develop self-assessment strategies.

Self assessment of progress can be carried out in a top-down manner through criterion descriptor training (see 4.2.) and bottom-up fashion, by focusing primarily on microstructure to provide a more thorough analysis at sentence, paragraph and text level.

As parallel corpus we have used a learner corpus of student translations with relevant problem segments extracted with the use of WordSmith Tools $®$ and tagged as "<problem> $<$ problem $>"$. We classified the segments to represent samples of problem and error types and offered students "filtered" concordances to assess their rendering of a particular segment against those of their peers. All texts were blind as regards the author of the translation and were classified by level of specialization and function.

This extract (Fig. 4) shows an example problem ST segment and student target text renderings. The concordance is obtained by searching for a particular key element that is predicted 
to appear in most translations (in the example the segment "97\%") and given to students in a whole sentence. Students grade renderings and explain particular error and problem types.

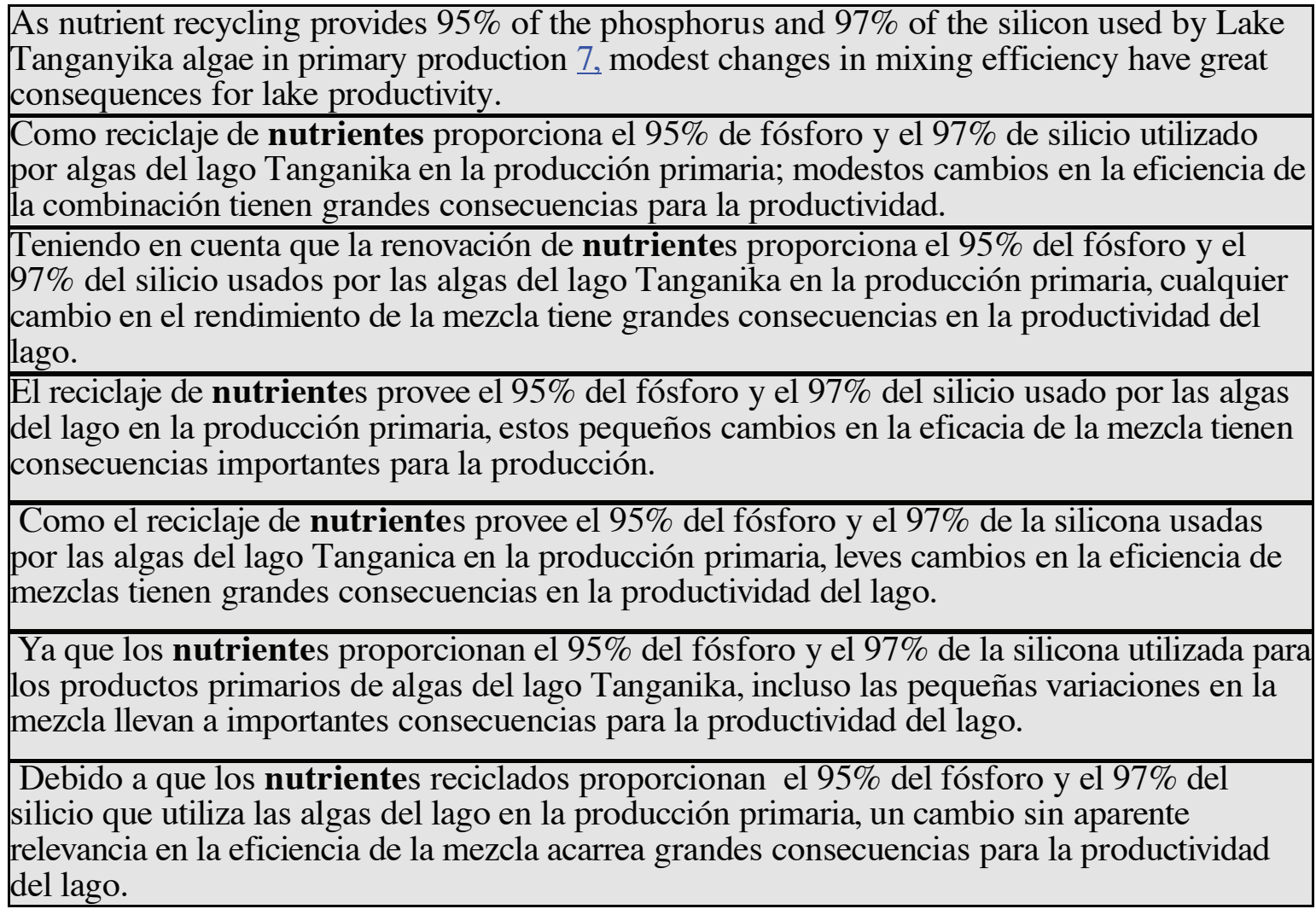

Figure 4. Source text segment from "The Heat on lake Tanganyika" (Nature 424, 731 - 732, 14 August 2003) and 6 of students' translations.

After choosing a specific segment as the most suitable equivalent for a particular source text segment, students had to explain and justify their decision on the basis of quality parameters (Laurscher 2000; López and Tercedor 2004).

\subsection{Self assessment of translations through criterion descriptor training}

In addition to the segment or paragraph approach seen above (4.1.), students can develop self assessment strategies through top-down analysis in which the focus is placed on the text as a whole and students infer conclusions from super- and macro- to micro-structural level. We developed a frame grading system that was further adapted to suit the conventions and idiosyncrasies of the various courses involved in the initiative: Scientific and technical translation English-Spanish for $3^{\text {rd }}$ year students, Scientific and Technical Translation Spanish-English for $4^{\text {th }}$ year students, Localization and Audiovisual translation English-Spanish for $4^{\text {th }}$ year students. We trained students in the use of the grading systems through multiple choice questionnaires. The criterion descriptors (below) are presented showing a left to right progress from decoding to encoding strategies and a vertical progression with regard to quality. 


\begin{tabular}{|c|c|c|c|c|}
\hline \multicolumn{2}{|c|}{ DECODING } & \multicolumn{3}{|l|}{ ENCODING } \\
\hline & Content & $\begin{array}{l}\text { Register, } \\
\text { vocabulary, } \\
\text { terminology }\end{array}$ & $\begin{array}{l}\text { Translation brief } \\
\text { and orientation to } \\
\text { target text type }\end{array}$ & Written expression \\
\hline 0 & $\begin{array}{l}\text { The text fails to } \\
\text { meet minimum } \\
\text { requirements }\end{array}$ & $\begin{array}{l}\text { The text fails to } \\
\text { meet minimum } \\
\text { requirements }\end{array}$ & $\begin{array}{l}\text { The text fails to } \\
\text { meet minimum } \\
\text { requirements }\end{array}$ & $\begin{array}{l}\text { The text fails to } \\
\text { meet minimum } \\
\text { requirements }\end{array}$ \\
\hline $1-2$ & $\begin{array}{l}\text { Comprehension very } \\
\text { limited. } \\
\text { Major content } \\
\text { errors. } \\
\text { Substantial } \\
\text { omissions of ST } \\
\text { content. }\end{array}$ & $\begin{array}{l}\text { Choice of register } \\
\text { inappropriate or } \\
\text { inconsistent. } \\
\text { Vocabulary very } \\
\text { limited with many } \\
\text { basic errors. } \\
\text { No awareness of } \\
\text { appropriate } \\
\text { terminology. . }\end{array}$ & $\begin{array}{l}\text { Formal or literal } \\
\text { translation. } \\
\text { Little or no use of } \\
\text { rhetorical devices } \\
\text { appropriate to TT } \\
\text { type. }\end{array}$ & $\begin{array}{l}\text { Very limited, } \\
\text { ineffective and } \\
\text { unclear. } \\
\text { Many errors in } \\
\text { basic } \\
\text { constructions. } \\
\text { Complex structures } \\
\text { are not attempted } \\
\text { or unclear. }\end{array}$ \\
\hline $3-4$ & $\begin{array}{l}\text { Comprehension } \\
\text { limited. } \\
\text { Minor content } \\
\text { errors. } \\
\text { Some omissions of } \\
\text { ST content. }\end{array}$ & $\begin{array}{l}\text { Choice of register } \\
\text { sometimes } \\
\text { inappropriate and. } \\
\text { inconsistent } \\
\text { Vocabulary limited } \\
\text { with some basic } \\
\text { errors. } \\
\text { Limited awareness } \\
\text { of appropriate } \\
\text { terminology. }\end{array}$ & $\begin{array}{l}\text { Elements of formal } \\
\text { or literal } \\
\text { translation. } \\
\text { Limited use of } \\
\text { rhetorical devices } \\
\text { appropriate to TT } \\
\text { type. }\end{array}$ & $\begin{array}{l}\text { Limited, barely } \\
\text { effective, } \\
\text { sometimes unclear. } \\
\text { Basic constructions } \\
\text { are accurate but } \\
\text { complex structures } \\
\text { are avoided or } \\
\text { unclear. }\end{array}$ \\
\hline $5-6$ & $\begin{array}{l}\text { Comprehension } \\
\text { adequate. } \\
\text { Minor omissions of } \\
\text { less relevant ST } \\
\text { content. } \\
\text { Over- or under- } \\
\text { translation } \\
\text { distorts ST content } \\
\text { or results in } \\
\text { ambiguity }\end{array}$ & $\begin{array}{l}\text { Choice of register } \\
\text { mostly appropriate } \\
\text { and consistent. } \\
\text { Vocabulary } \\
\text { effective despite } \\
\text { errors. } \\
\text { Terminology } \\
\text { appropriate despite } \\
\text { errors. }\end{array}$ & $\begin{array}{l}\text { Clear orientation } \\
\text { towards TT type. } \\
\text { Appropriate use of } \\
\text { many TT type } \\
\text { rhetorical devices }\end{array}$ & $\begin{array}{l}\text { Effective and } \\
\text { clear. } \\
\text { Complex structures } \\
\text { are clear. } \\
\text { Some errors in use } \\
\text { of articles, } \\
\text { prepositions or } \\
\text { spelling of less } \\
\text { common words. }\end{array}$ \\
\hline $7-8$ & $\begin{array}{l}\text { Comprehension good. } \\
\text { Over- or under- } \\
\text { translation does } \\
\text { not distort ST } \\
\text { content or result } \\
\text { in ambiguity. }\end{array}$ & $\begin{array}{l}\text { Choice of register } \\
\text { generally } \\
\text { appropriate and } \\
\text { consistent. } \\
\text { Vocabulary } \\
\text { effective despite } \\
\text { mistakes. } \\
\text { Terminology } \\
\text { appropriate despite } \\
\text { mistakes. }\end{array}$ & $\begin{array}{l}\text { Effective } \\
\text { production of TT } \\
\text { type. } \\
\text { Consistently } \\
\text { appropriate use of } \\
\text { TT type rhetorical } \\
\text { devices }\end{array}$ & $\begin{array}{l}\text { Good and effective. } \\
\text { Systematic errors } \\
\text { of advanced usage } \\
\text { only. } \\
\text { Occasional } \\
\text { mistakes. }\end{array}$ \\
\hline $9-10$ & $\begin{array}{l}\text { Comprehension very } \\
\text { good. } \\
\text { ST content fully } \\
\text { understood. }\end{array}$ & $\begin{array}{l}\text { Choice of register } \\
\text { consistently } \\
\text { effective and } \\
\text { appropriate. } \\
\text { Vocabulary wholly } \\
\text { accurate with some } \\
\text { sophistication. } \\
\text { Terminology } \\
\text { appropriate and } \\
\text { largely accurate. }\end{array}$ & $\begin{array}{l}\text { Effective, } \\
\text { sophisticated } \\
\text { production of TT } \\
\text { type with few } \\
\text { errors. }\end{array}$ & $\begin{array}{l}\text { Very good. } \\
\text { Sophisticated use } \\
\text { of language with } \\
\text { few or no errors of } \\
\text { advanced usage and } \\
\text { occasional mistakes } \\
\text { only. }\end{array}$ \\
\hline
\end{tabular}




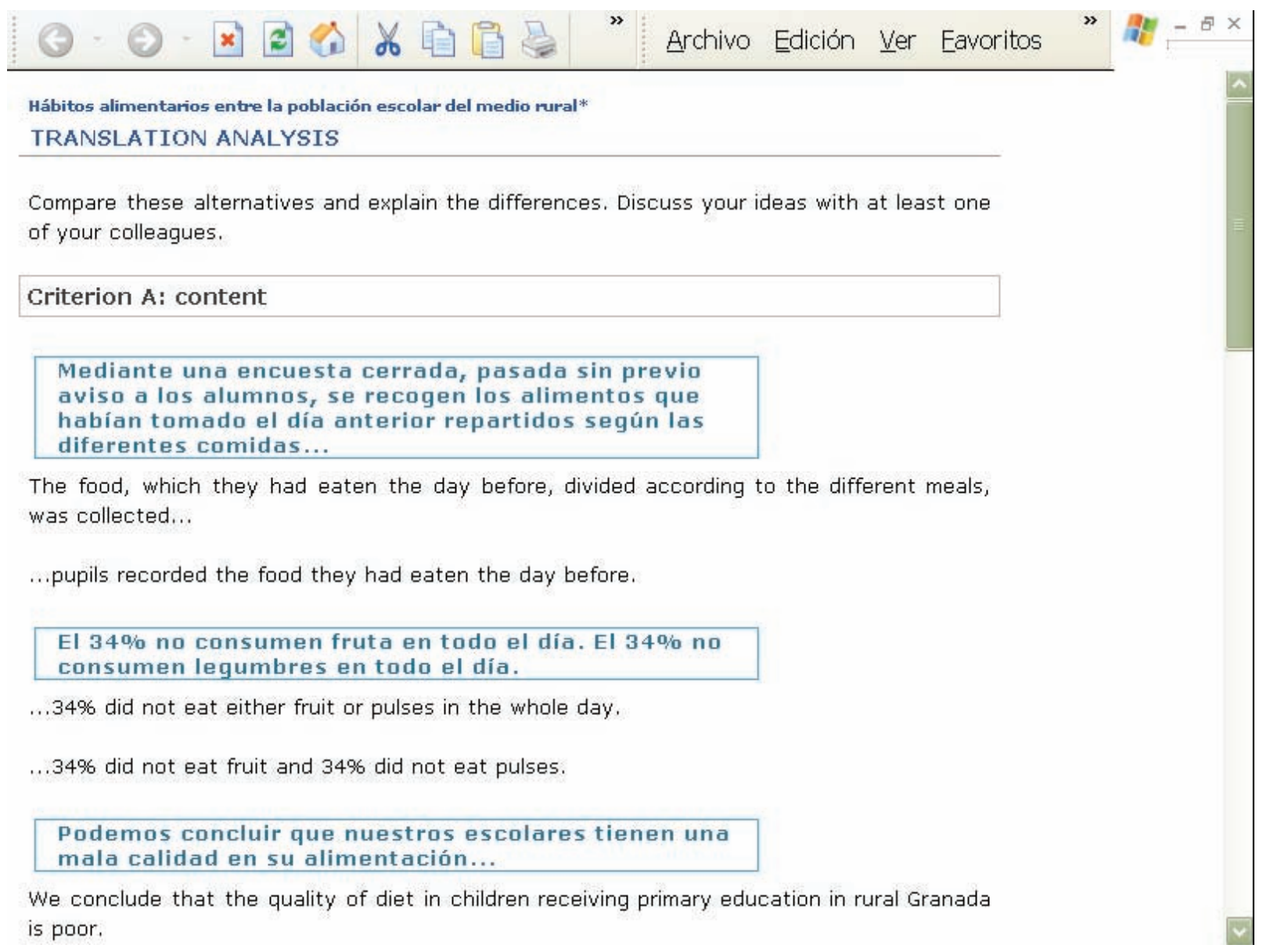

Figure 6. Scaffolding: a learning frame to develop self-evaluation competence.

Students are taken through the process of distinguishing between different Target Text versions of phrases drawn from the learner corpora in order to identify the difficulties they entail and select the alternatives they prefer with reference to the criterion descriptors. Initially, they focus in the left-toright columns to identify error types. Figure 5 shows errors of content. They are then expected to 'rank' the translation fragments on the vertical 0 to 10 scale. These activities lead them towards a fuller understanding of the errors they typically commit and the ability to identify their own and their peers' errors, to classify these in terms of type (using the left-to-right criterion labels) and in terms of seriousness (using the vertical 0 to 10 scale).

\subsection{Self assessment through multiple choice questionnaires}

Multiple choice questionnaires are used extensively and prove useful testing instruments in many disciplines. In our research, they have demonstrated their efficiency when dealing with topics such as:

a) Relevant theoretical questions and research articles that learners should be familiar with

b) Becoming familiar with standard text structures or formats as a key to identify the text type and convention (i.e. a particular superstructure such as that of a resource file in localization)

c) Identifying particular metaphors in a domain (as a cognitive resource) or a particular text (as a textual element) (cf. question 9 on figure 7) 
d) Getting acquainted with standard translations in highly technical documents (question 10 on figure 7)

e) Identifying the function and focus of an image in relation to a text through matching exercises. We here have used several images representing the same concept from different perspectives on one column and their matching texts on another column.

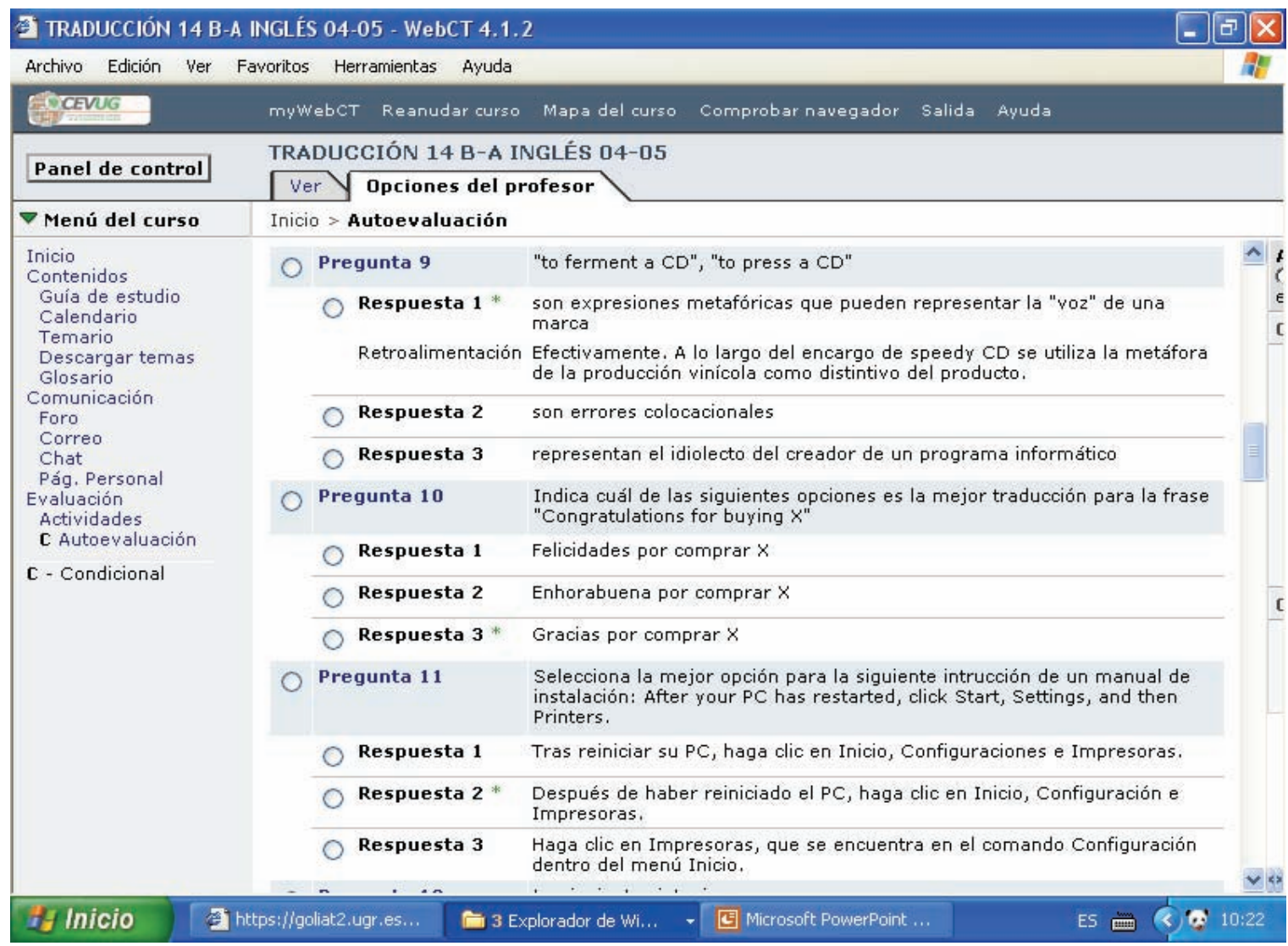

Figure 7. Screenshot of a multiple choice questionnaire from the course on Localization on the webCT platform.

These topics help students with theoretical issues as well as with text conventions of different genres. However, we believe it is necessary to warn against the use of this sort of tool for assessing translations as there a proposal might be seen as the translation for a particular segment.

\section{Moving away from the text-centered approach: assessing the image-text interrelation in class}

Today's professional environment has new implications as regards the work demanded from the translator. These include the shift towards new concepts of translation that include focusing on non textual information to produce translation or technical writing solutions.

Translation courses must assess the new sorts of activities that are being demanded from the translator and that are not accounted for in the traditional definitions of what the translation practice is (as Maria Tymozcko points out in the current volume). Given the nature of the courses we work with, we place special emphasis on the importance of visual and graphic information in texts. We take the view that: 
a) the presence of images is not fortuitous in the text

b) the image directs the reader attention to a particular aspect on the text

c) images can be classified by register, level of expertise and geographical relevance

It is useful to try and classify images according to their function within the textual structure and the perception the user has of them as regard their relationship with the concept or text they serve. This brings us to culturally oriented images and the need to try and find solutions to word plays accompanied by images such as it often happens in localization (Tercedor 2005).

As cognitive support for the text, the image should contain basic level categories of the text it accompanies. In a process oriented html document on recycling (below), the image clearly represents the process described in the text.

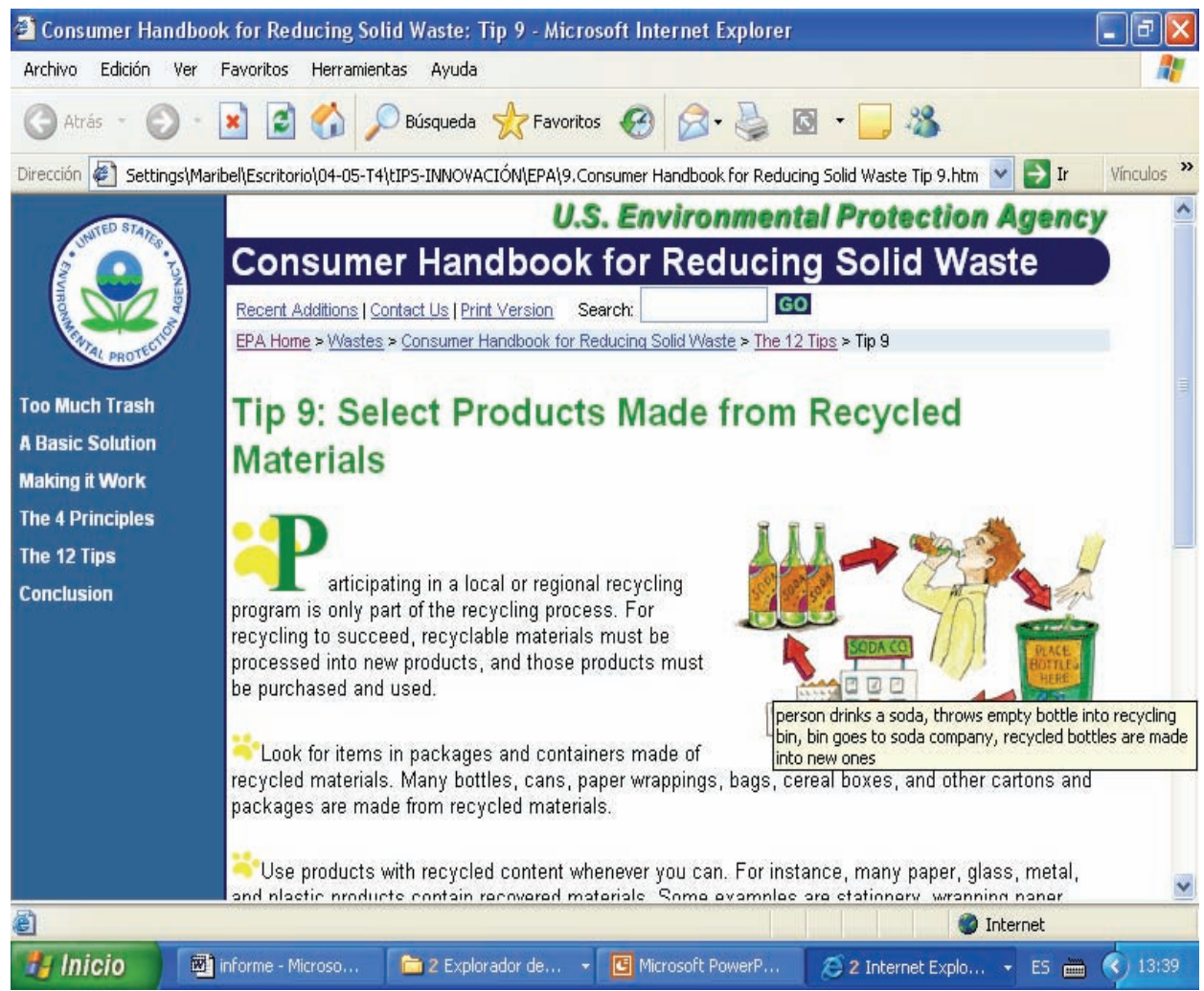

Figure 8. Extract from "Tips for reducing solid Waste". http://www.epa.gov/epaoswer/nonhw/reduce/catbook/the12.htm

\subsection{Working towards accessibility in translation}

\section{Accessibility puts the multi in media}

J. Clark (2002)

The current context of university translation teaching demands we consider concepts such as accessibility and usability. As the W3Consortion suggests, creating accessible content means that the content can be used by people regardless of disability; by the same token, translating html and $\mathrm{xml}$ documents has necessarily to include training in how to deal with these two concepts in a way that students (1) learn how to analyze drawbacks for accessibility in a web site (2) acquire the basic knowledge to provide a web based document with textual solutions that boost accessibility. 
We propose activities that include the writing of text descriptions in the 'alt' attribute of an html document to make web sites accessible for people who cannot access visual information in images. Alternative sources of information that improve accessibility are captions and "collated text transcripts" (caption text with text descriptions of video information) for videos (Haritos-Shea 2002).

In contrast with the text description in the image shown above (Fig. 8), there are many technical and scientific web documents which lack text descriptions in images accompanying texts and make it impossible for the image to be retrieved by search engines. In other cases, the descriptions offered are poor in the sense that:

(i) the same description is given for different pictures in the site,

(ii) the description is two short to be informative enough or two long to be retrieved by text-to Braille conversion tools.

When approaching the translation of these documents, students are encouraged to propose a text description for the image that requires one:

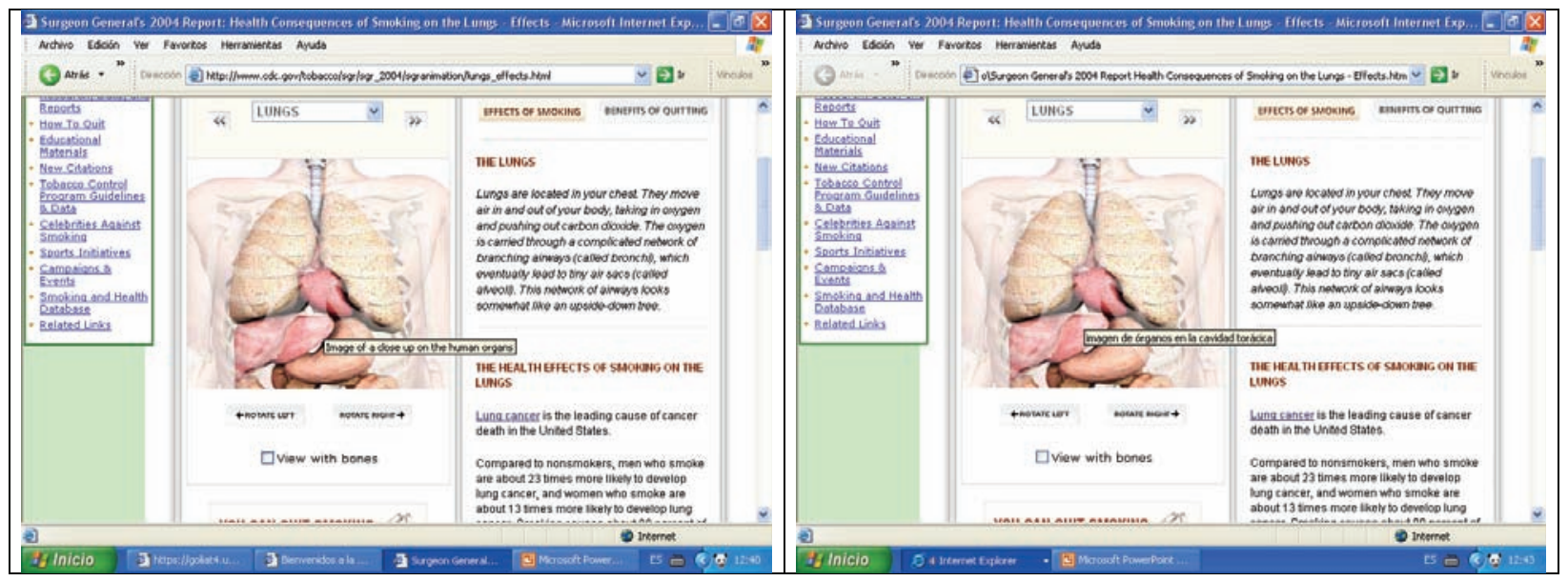

Figure 9. English source text with image with inadequate text description (left). Spanish translated text with text description for image to boost accessibility.

We believe that these exercises, in addition to being highly motivating, also illustrate the importance of the image in the new web based document types as a key to register, function of text and focus of information.

\section{Conclusion}

Developing aids for courses in audiovisual, scientific and technical translation can address the challenges of the accessible IT society through the use of multimedia text types and by responding to the new tasks demanded of translators through boosting the use of corpora in class and carrying out translation related activities that imply focusing on textual and non textual material as a means of studying register and focus of information.

In the context of e-learning, the concept of scaffolding must be taken into account in order to follow an approach in which partial tasks are components of a methodology in which teachers act as facilitators of the learning process. 


\section{NOTES}

* This paper has been carried out as part of the work of the Puertoterm R\&D Project Code BF 2003-04720 funded by the Spanish Ministry of Science and Technology and the innovation action "Localización del texto multimedia: generación de recursos en el aula de traducción científica y técnica" funded by the University of Granada. 


\section{REFERENCES}

BOwKER, L. (1998): "Using Specialized Monolingual Native-Language Corpora as a Translation Resource: A Pilot Study", Meta 43-4, pp. 631-651.

CLARK, J. (2002): Building accessible web sites. Indianapolis, New Riders Publishing.

FUNDACIÓN AUNA (2004): eEspaña 2004. Informe anual sobre el desarrollo de la Sociedad de la Información en España. Madrid, Ed. Fundación Auna.

GONZÁLEZ DAVIES, M (2004): Multiple voices in the Translation Classroom, Amsterdam, John Benjamins.

HALVERSON, S. (1998): "Translation Studies and Representative Corpora: Establishing Links between Translation

Corpora, Theoretical/Descriptive Categories and a Conception of the Object of Study", Meta 43- 4, pp. 1-22.

HARITOS-SHEA, K. (2002): «Techniques for Authoring Tool Accessibility Guidelines 1.0. Glossary»,

W3Consortium note, 29 October 2002. Document available at: http://www.w3.org/TR/ATAG10-

TECHS/glossary\#def-transcript

Kenny, D. (2001): Lexis and Creativity in Translation: A Corpus-based Study, Manchester, St. Jerome

Publishing.

KIRALY, D. (2000): A Social Constructivist Approach to Translator Education, Manchester, St. Jerome.

LAURSCHER, S. (2000): "Translation quality assessment: Where can theory and practice meet?", The Translator 6- 2, pp. 149-168.

LAFFling, J. (1992): "On Constructing a Transfer Dictionary for Man and Machine", Target 4-1, pp. 17-31.

LÓPEZ-RodríGueZ, C. I. and M. I. TERCEDOR-SÁNCHEZ (2004): "Problemas, evaluación y calidad en traducción científica y técnica", Sendebar 15, pp. 29-43.

PASSMORE, J. (1970): The Perfectibility of Man, London, Duckworth.

Peters, C. and E. PiCCHI (1997): "Reference corpora and lexicon for translators and translation studies". In A.

Trosborg (ed). Text Typology and Translation. Amsterdam/Philadelphia, John Benjamins, pp.247-274.

Peters, C., E. PICCHI and L. BIAGINI (1996): "Parallel and comparable bilingual corpora in language teaching and learning". In S. Botley et al. (eds). Proceedings of Teaching and Language Corpora (UCREL Technical Papers, Volume 9). Lancaster, University of Lancaster, pp. 68-80.

RoBinson, B.J. (1998): "Traducción transparente: métodos cuantitativos y cualitativos en la evaluación de la traducción", Revista de Enseñanza Universitaria. Sevilla, I.C.E., Universidad de Sevilla, Número extraordinario, pp. 577-589. 